\title{
Multiple Activities of the Plant Pathogen Type III Effector Proteins WtsE and AvrE Require WxxxE Motifs
}

\author{
Jong Hyun Ham, ${ }^{1,2}$ Doris R. Majerczak, ${ }^{2}$ Kinya Nomura, ${ }^{3}$ Christy Mecey, ${ }^{3}$ Francisco Uribe, ${ }^{3}$ \\ Sheng-Yang He, ${ }^{3}$ David Mackey, ${ }^{1}$ and David L. Coplin ${ }^{2}$ \\ ${ }^{1}$ Department of Horticulture and Crop Science and ${ }^{2}$ Department of Plant Pathology, The Ohio State University, Columbus \\ 43210, U.S.A.; ${ }^{3} \mathrm{MSU}-\mathrm{DOE}$ Plant Research Laboratory, Michigan State University, East Lansing 48824, U.S.A.
}

Submitted 3 December 2008. Accepted 10 February 2009.

\begin{abstract}
The broadly conserved AvrE-family of type III effectors from gram-negative plant-pathogenic bacteria includes important virulence factors, yet little is known about the mechanisms by which these effectors function inside plant cells to promote disease. We have identified two conserved motifs in AvrE-family effectors: a WxxxE motif and a putative C-terminal endoplasmic reticulum membrane retention/retrieval signal (ERMRS). The WxxxE and ERMRS motifs are both required for the virulence activities of WtsE and AvrE, which are major virulence factors of the corn pathogen Pantoea stewartii subsp. stewartii and the tomato or Arabidopsis pathogen Pseudomonas syringae pv. tomato, respectively. The WxxxE and the predicted ERMRS motifs are also required for other biological activities of WtsE, including elicitation of the hypersensitive response in nonhost plants and suppression of defense responses in Arabidopsis. A family of type III effectors from mammalian bacterial pathogens requires $\mathrm{WxxxE}$ and subcellular targeting motifs for virulence functions that involve their ability to mimic activated G-proteins. The conservation of related motifs and their necessity for the function of type III effectors from plant pathogens indicates that disturbing host pathways by mimicking activated host G-proteins may be a virulence mechanism employed by plant pathogens as well.
\end{abstract}

Many gram-negative bacterial pathogens of plants and animals utilize type III secretion systems (TTSS) to deliver bacterial virulence proteins into eukaryotic host cells (He et al. 2004). The translocated proteins, which are called type III effectors, serve to promote infection by modulating host cellular processes such as cytoskeleton dynamics, host immune responses, and cell death (Gohre and Robatzek 2008). A plant-pathogenic bacterium usually produces and secretes more than 20 different effector proteins, presumably to block or avoid eliciting host resistance responses and to release nutrients from host tissues in order to support the rapid increase of bacterial populations in infected plants. With a few exceptions, the virulence functions of most type III effectors in plant-pathogenic bacte-

Corresponding authors: D. Coplin; Telephone: 614-292-8503; Fax: 614292-4455; E-mail: coplin.3@osu.edu; and D. Mackey; Telephone: 614292-5879; Fax: 614-292-7162; E-mail: mackey.86@osu.edu

Current address for J. H. Ham: Department of Plant Pathology and Crop Physiology, Louisiana State University AgCenter, Baton Rouge 708031720, U.S.A

* The $\boldsymbol{e}$-Xtra logo stands for "electronic extra" and indicates that one supplemental table and three supplemental figures are published online. Also, Figures 2, 4, and 5 appear in color online. ria remain poorly understood (da Cunha et al. 2007; Speth et al. 2007).

AvrE-family effector proteins are among the most important virulence factors in plant-pathogenic bacteria and are unique in several respects. First, AvrE-family effectors are widely conserved in the divergent genera Pseudomonas, Pantoea, Erwinia, Dickeya, and Pectobacterium. These effectors are encoded by genes that are physically adjacent to the Hrp TTSS gene cluster as part of a large pathogenicity island (PAI). Because acquisition of this PAI is believed to play an essential role in the evolution of many bacterial plant pathogens, the virulence function of AvrE-family effectors is likely to be central to pathogenesis. Second, although it has been difficult to demonstrate a role of many type III effectors in virulence using mutational approaches, the role of AvrE-family effectors in virulence is well recognized. Most significantly, DspE (alternatively named DspA) of the fire blight pathogen Erwinia amylovora and WtsE of Pantoea stewartii subsp. stewartii are essential pathogenicity factors because the virulence reduction of the $d s p E$ and wtsE mutants is comparable with that of TTSS-defective mutants (Bogdanove et al. 1998; Frederick et al. 2001). An important role for AvrE-family effectors in virulence has also been shown in strains of Pseudomonas syringae pv. tomato and, interestingly, the function of AvrE appears to be redundant to that of HopM1 in P. syringae pv. tomato DC3000 (Badel et al. 2006; DebRoy et al. 2004; Lorang and Keen 1995). Third, AvrE-family effectors are very large proteins (most are $>200$ $\mathrm{kDa}$ ) with dual functions in promoting symptoms associated with host cell death and in suppressing basal defenses (Boureau et al. 2006; DebRoy et al. 2004; Ham et al. 2008). Despite their importance, the molecular mechanisms by which AvrE-family effectors carry out their virulence functions are not understood. In this study, we investigated WtsE from Pantoea stewartii subsp. stewartii, which causes Stewart's bacterial wilt and leaf blight of sweet corn and maize, and AvrE from $P$. syringae pv. tomato, which causes bacterial speck of tomato and a leaf spot on Arabidopsis thaliana. Although WtsE and AvrE are each members of this large family (Fig. 1), the two proteins are fairly divergent, with only $27.1 \%$ amino acid identity.

Recently, Alto and associates (2006) reported that members of a family of type III effectors from animal pathogens, including Escherichia coli, Shigella spp., and Salmonella spp., perturb host functions by mimicking constitutively active Ras-like G-proteins. Despite producing the same effects as activated Gproteins, these effectors do not bind guanine nucleotides or possess apparent GTPase domains. Moreover, they all contain a WxxxE motif that is essential for their function as G-protein mimics. In addition, these effectors also possess various $\mathrm{C}$-ter- 
minal subcellular localization signals. In this study, we report that nearly all of the AvrE-family members contain one or two WxxxE motifs and a putative C-terminal endoplasmic reticulum membrane retention/retrieval signal (ERMRS). We used site-directed mutagenesis to inactivate both of the WxxxE motifs or the predicted ERMRS in Pantoea stewartii subsp. stewartii WtsE and $P$. syringae pv. tomato AvrE and then tested their biological activities in host and nonhost plants. Our results demonstrate that both the WxxxE and predicted ERMRS motifs are required for multiple virulence and avirulence activities of AvrE-family effector proteins, which suggests that the AvrE-family effectors might mimic activated plant G-proteins. This would be a new mode of action for TTSS effector proteins from plant-pathogenic bacteria.

\section{RESULTS}

\section{AvrE-family type III effectors contain WxxxE motifs.}

Recently, type III effector proteins from several animalpathogenic bacteria were shown to alter host cells by mimicking activated Ras-like GTPases (Alto et al. 2006; Arbeloa et al. 2008) and this activity depends on invariant WxxxE motifs and eukaryotic subcellular localization signals. We examined the available sequences of AvrE-family proteins and found that they form two major clades (Fig. 1), representing the erwinias and the pseudomonads. Moreover, the amino-terminal halves of members of both clades contain WxxxE motifs. AvrE homologs from Pantoea stewartii subsp. stewartii, E. amylovora, E. pyrifoliae, $P$. syringae pv. tomato, $P$. syringae pv. phaseolicola $1448 \mathrm{~A}$, and $P$. cichorii possess two WxxxE motifs, while those from Pantoea agglomerans pv. gypsophilae, $P$. syringae pv. syringae B728a, and P. fluorescens SBW45 (RopE) have only one WxxxE. Recently, Araki and associates (2007) released the sequences of 96 AvrE homologs from strains of $P$. viridiflava, a pathogen of $A$. thaliana. These strains contained either of two different Hrp PAI, each with a slightly diverged avrE allele. All 96 AvrE proteins from $P$. viridiflava contained two WxxxE motifs.

Arbeloa and associates (2008) reported that EspM2 and EspM3, WxxxE-containing mammalian effectors from Citrobacter rodentium, retained function when their $\mathrm{W} x x x E$ motifs were mutated with conservative $\mathrm{W}$ to $\mathrm{Y}$ or $\mathrm{E}$ to $\mathrm{D}$ substitutions, whereas changing either $\mathrm{W}$ or $\mathrm{E}$ to $\mathrm{A}$ disrupted their function. We have determined that the AvrE-family proteins contain seven highly conserved Ws (Supplementary Fig. 1). Those sites with substitutions of $\mathrm{Y}$ or $\mathrm{F}$ for $\mathrm{W}$ and $\mathrm{D}$ or other positively charged residues for E may be functional variants of the WxxxE motif.

Similar to the G-protein-mimicking mammalian effectors, most AvrE-family proteins also contain a putative subcellular localization motif at their C-termini. In our previous studies, we found a motif at the C-terminus of WtsE (KKEGFEMK) that is predicted by the PSORT II algorithm to function as an ERMRS (Fig. 1) and we demonstrated that this motif is essential for the virulence and avirulence activities of WtsE (Ham et al. 2006, 2008). Among AvrE-family members examined, PSORT II predicted a C-terminal ERMRS (KKxGxExK) for all of the effectors except DspE from Pectobacterium atrosepticum and the AvrE alleles from $P$. viridflava strains containing one of the two alternative Hrp PAI (representative AvrE homologs from $P$. viridiflava with and without an ERMRS are shown in Figure 1).

\section{The WxxxE motifs are required}

for WtsE-induced cell death in host and nonhost plants.

To study the cell death activity of WtsE in the absence of any other TTSS effector proteins produced by Pantoea stewartii subsp. stewartii, we employed Escherichia coli MC4100 carrying the entire Dickeya dadantii hrp gene cluster in plasmid pCPP2156 as a delivery system for WtsE, which was encoded by derivatives of plasmid pJH021 wtsEF $F^{+}$The $D$. dadantii TTSS has been shown to promiscuously translocate effectors from many different plant-pathogenic bacteria (Ham et al. 1998) and it has worked well to introduce WtsE into sweet corn, tobacco, and Nicotiana benthamiana (Ham et al. 2006, 2008). Changing either the $\mathrm{W}$ or $\mathrm{E}$ residue to $\mathrm{A}$ in the WxxxE motifs of mammalian effectors resulted in loss of Gprotein-mimicking activity (Alto et al. 2006; Arbeloa et al. 2008); therefore, we changed the $\mathrm{W}$ residue in each of the two WxxxE motifs of WtsE to A; W694A and W840A mutations were constructed by site-directed mutagenesis in plasmid pJH021. The single mutants were designated WtsE-w1 and WtsE-w2, respectively, and the double mutant was designated
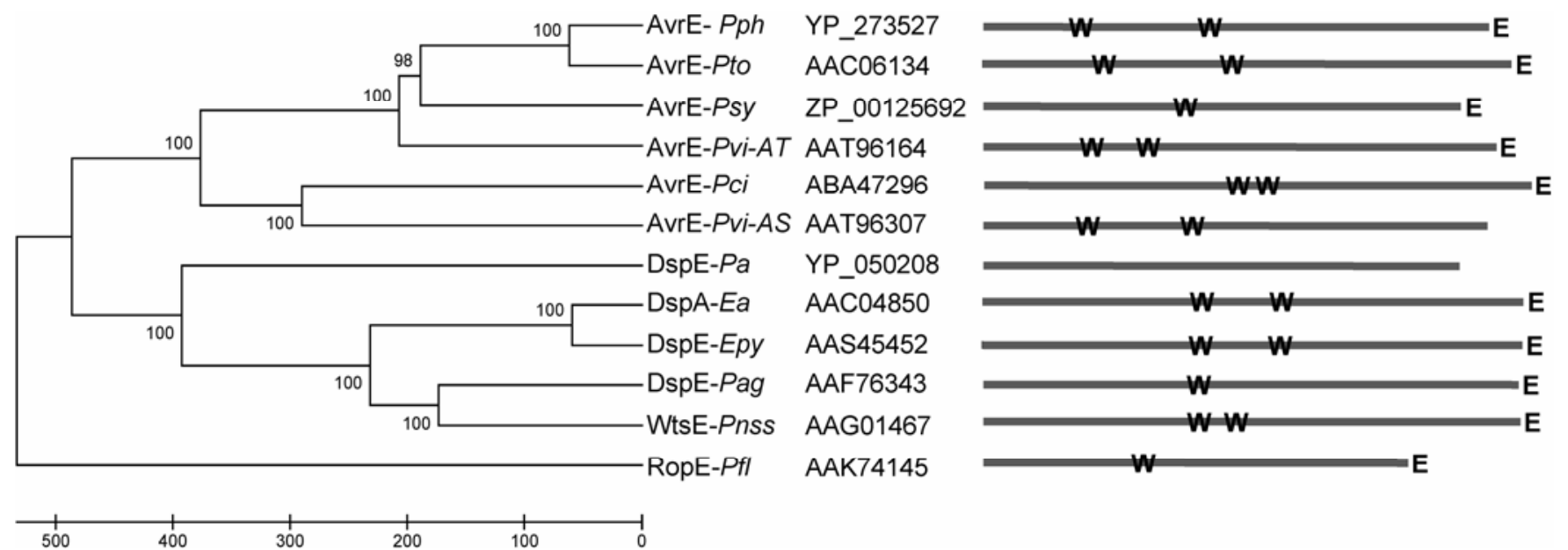

Fig. 1. Presence of WxxxE and endoplasmic reticulum membrane retention/retrieval signal (ERMRS) motifs in AvrE-family effector proteins of plant-associated bacteria. Phylogenetic tree of the AvrE-family effector proteins from plant-pathogenic bacteria. Genus and species abbreviations after each protein are as follows: Pph (Pseudomonas syringae pv. phaseolicola 1448A), Pto (P. syringae pv. tomato DC3000), Psy (P. syringae pv. syringae B728a), Pvi-AT (P. viridiflava LP23.1a), Pci (P. cichorii 83-1), Pvi-AS (P. viridiflava RMX23.1a), Pa (Pectobacterium atrosepticum SCRI1043), Ea (Erwinia amylovora Ea321), Epy (E. pyrifoliae WT3), Pag (Pantoea agglomerans pv. gypsophilae Ehg284-1), Pnss (Pantoea stewartii subsp. stewartii SS104), and Pfl (P. fluorescens SBW25). Also shown are the GenBank accession number for each protein. This neighbor-joining tree is built based on the observed number of amino acid differences. Bootstrap values $(\%)$ are shown beside each branch and the units at the bottom indicate the number of amino acid differences. To the right are stick diagrams showing the position of WxxxE motifs $(\mathrm{W})$ and putative ERMRSs (E). 
WtsE-w12. We previously deleted amino acids 1,831 to 34 (FEMK) within the putative ERMRS (Ham et al. 2008) and designated this mutant $\triangle$ FEMK.

We first tested the ability of the wtsE W694A and W840A mutants to cause disease-associated cell death in susceptible plants. Corn leaves were vacuum-infiltrated with Escherichia coli MC4100 (pCPP2156) strains delivering the WtsE derivatives, and water-soaking (Wts) and necrosis were both rated visually in corn seedlings and quantified by measuring electrolyte leakage (EL) from corn leaf discs. Wild-type WtsE caused severe Wts and substantial EL (Fig. 2A). Disruption of either of the two WxxxE motifs alone did not significantly reduce the amount of Wts, although the w1 mutant did reduce EL. However, the w12 and $\triangle$ FEMK mutants both failed to cause cell death or EL (Fig. 2A).

In addition to causing disease-associated cell death in susceptible plants, WtsE also causes a rapid hypersensitive response (HR) in nonhost plants (Ham et al. 2008). To determine whether the WxxxE motifs and the putative ERMRS are also required for HR elicitation, we infiltrated the Escherichia coli delivery strains into $N$. benthamiana (Fig. 2B) and tobacco leaves (Supplementary Fig. 2). Again, wild-type WtsE and the w1 and w2 single mutants elicited a strong HR, whereas the w12 and $\triangle$ FEMK mutants did not. Similar results were obtained when WtsE or the derivatives were delivered into $N$. benthamiana by agroinfiltration or by Pantoea stewartii subsp. stewartii (Supplementary Fig. 3). Collectively, these results indicate that the WxxxE motifs are functionally redundant and that both the C-terminal ERMRS and the WxxxE motifs within WtsE are required for both HR elicitation in nonhost plants and disease-associated cell death in susceptible plants.

\section{The WxxxE motifs in WtsE are required}

\section{for full virulence of Pantoea stewartii in host plants.}

The w1, w2, w12, and $\triangle$ FEMK mutations, as well as a triple w12/AFEMK mutation, were introduced into the Pantoea stewartii subsp. stewartii DC283 genome by homologous recombination. Sweet corn seedlings were inoculated with these mutants by placing bacterial suspensions into the whorls, and then disease severity was rated daily for 5 days. Disrupting either one of the WxxxE motifs did not significantly alter the ability of Pantoea stewartii subsp. stewartii to cause water-soaked lesions, as shown by both the final disease severity rating and the area under the disease progress curve (Fig. 3A). The w12 mutation resulted in significant loss of virulence, again indicating that the two WxxxE motifs are functionally redundant. A comparable reduction was observed for the $\triangle F E M K$ mutant but this level was not reduced any further in the triple w12/AFEMK mutant. The virulence of the w12, $\triangle$ FEMK, and triple mutants was fully restored by complementation with plasmid pAA007 wtsEF $F^{+}$, with disease severity ratings of 2.8 to $3.0 \pm 0.3$ for all mutants and the DC283 parent strain at 5 days after inoculation. These results indicate that the WxxxE and putative ERMRS motifs likely contribute to the same virulence function of WtsE and that the w12 or $\triangle$ FEMK mutations each fully disrupt this activity.

The growth of the wild-type and mutant Pantoea stewartii subsp. stewartii strains in sweet corn plants was also examined (Fig. 3B). In contrast to the reduction in symptoms, the growth of the w12, $\triangle$ FEMK, and w12/ $\triangle$ FEMK mutant strains was not significantly compromised. Each of these mutants grew significantly better than the wtsE null mutant, AA005, and a TTSSdeficient mutant, DM711 hrpJ. Thus, the mutant WtsE proteins apparently retain an additional growth-promoting virulence function that does not require WxxxE or ERMRS motifs, at least under the experimental conditions used in this study. In addition to promoting Pantoea stewartii subsp. stewartii growth, the $\mathrm{w} 12$ and $\triangle$ FEMK mutants retain other activities, including some slight residual cell death activity in $N$. benthamiana and production of a few lesions in sweet corn (Fig. 2A), which were not observed with a wtsE null mutant. The relationship of these functions to the variants of $\mathrm{WxxxE}$ motifs and to G-protein mimicry is unknown.

To determine whether the altered virulence of the mutant strains is caused by changes in the production, stability, or secretion of the WtsE derivatives from Pantoea stewartii subsp. stewartii, we did Western blots of cell extracts and supernatants using antibodies to E. amylovora DspE, which cross-react with WtsE. All of the WtsE derivatives exhibited normal production and secretion in culture. Evidence that wild-type WtsE can be expressed and delivered from Escherichia coli MC4100
A

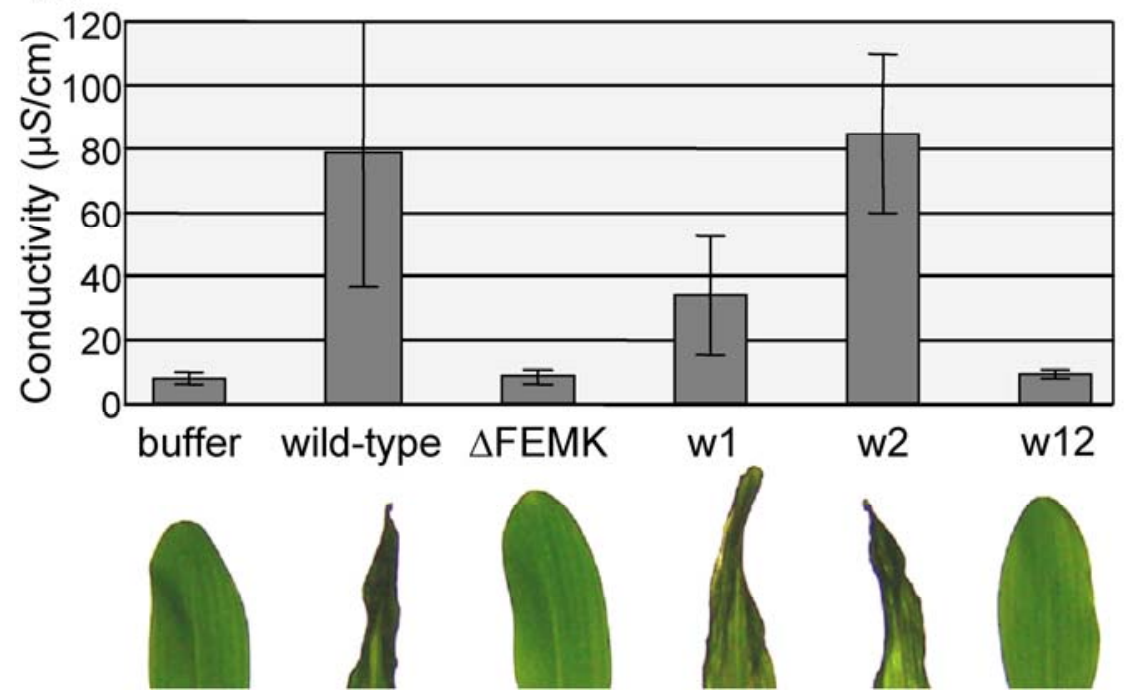

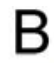

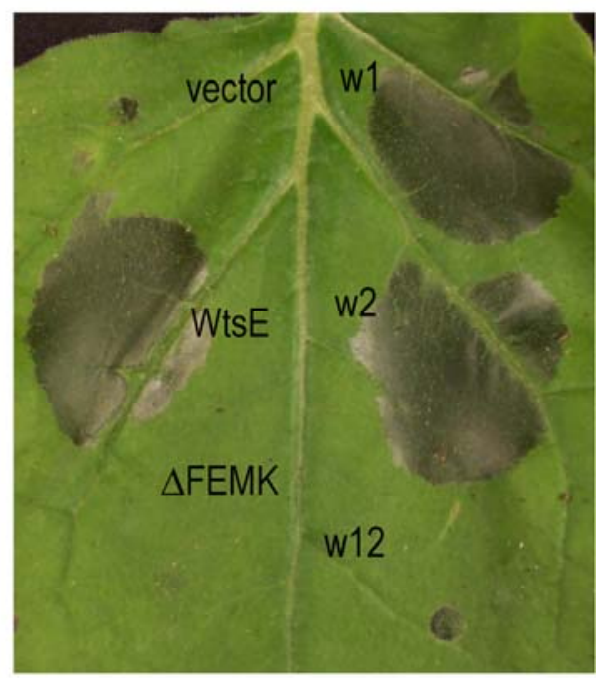

Fig. 2. Cell death phenotypes induced by delivery of WtsE from Escherichia coli into host and nonhost plants. A, Photographs of corn seedling leaves (below) and corresponding ion leakage data (above) following infiltration with Escherichia coli MC4100 (pCPP2156) strains delivering wild-type WtsE or the indicated derivatives. Each WtsE plasmid also encodes the chaperone WtsF. Conductivity values are means \pm standard deviation for three replications. B, Photograph of the hypersensitive response in Nicotiana benthamiana following delivery of WtsE or the indicated derivatives from Escherichia coli. Photographs were taken at 15 to $18 \mathrm{~h}$ after infiltration and conductivity assays were done at $18 \mathrm{~h}$ after infiltration. Results are representative of three independent experiments. 
(pCPP2156) and from $P$. syringae pv. phaseolicola (discussed below) comes from its in planta activity following delivery by these systems. Because the studied mutations do not affect type III secretion from Pantoea stewartii subsp. stewartii, they are similarly unlikely to affect type III secretion in the Escherichia coli/hrp $_{D d a}$ or $P$. syringae pv. phaseolicola systems. Efforts to monitor in planta production and stability of WtsE following Agrobacterium-mediated transient expression failed to detect WtsE or its derivatives (data not shown). However, the ability of the wtsE-w12 and wtsE- $\triangle F E M K$ mutants to promote Pantoea stewartii subsp. stewartii lesions and growth relative to the wtsE null mutant (Fig. 3) indicates that the mutant proteins accumulate and retain some function in corn cells.

WxxxE and predicted ERMRS motifs are responsible for cell death and defense suppression activities of WtsE in A. thaliana.

P. syringae pv. phaseolicola NPS3121 is a bean pathogen that is nonpathogenic in A. thaliana. Although $P$. syringae pv. phaseolicola does not elicit an HR in A. thaliana, it does elicit strong basal defense responses, including PR-1 protein production and callose deposition in the cell wall (Ham et al. 2007). When $P$. syringae pv. phaseolicola expresses HopM1, which is functionally redundant to AvrE, these defenses are suppressed (Ham et al. 2007). From the genome sequence of $P$. syringae pv. phaseolicola 1448A (Joardar et al. 2005), a strain closely related to $P$. syringae pv. phaseolicola NPS3121, it is known that hopMl is truncated and AvrE is intact (Badel et al. 2006). Apparently, P. syringae pv. phaseolicola NPS3121 lacks versions of HopM1 and AvrE that can fully defeat basal resistance in Arabidopsis. We previously reported that $P$. syringae pv. phaseolicola translocates WtsE into A. thaliana, where it induces Wts and suppresses callose formation and the synthesis of PR-1 (Ham et al. 2008). Here, we tested the effects of the w12 and $\triangle$ FEMK mutations on these virulence activities of WtsE. $P$. syringae pv. phaseolicola expressing either wild-type WtsE or HopM1 caused tissue collapse of A. thaliana at $24 \mathrm{~h}$ after infiltration with a bacterial suspension $\left(1 \times 10^{8} \mathrm{CFU} / \mathrm{ml}\right)$
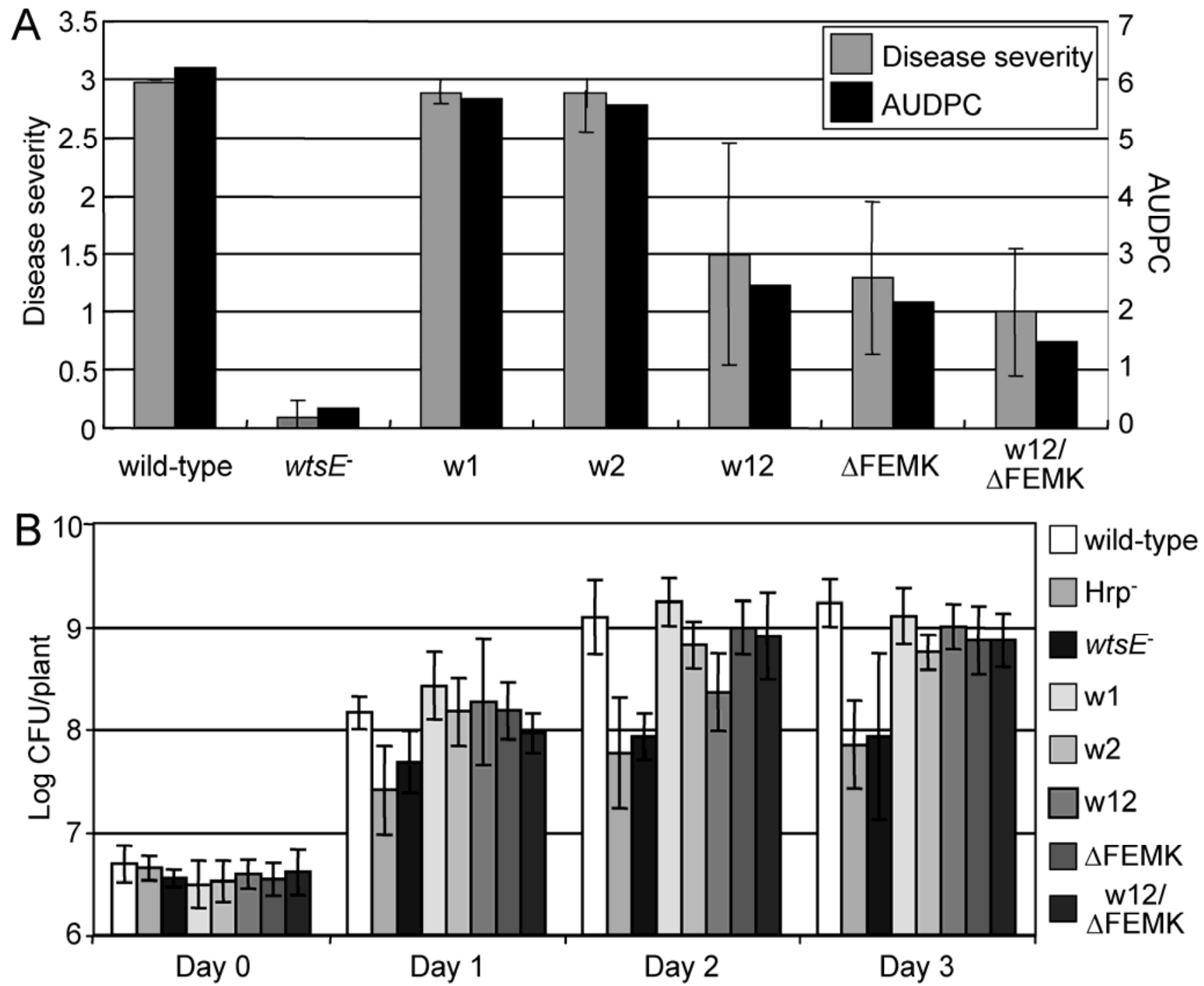

Fig. 3. Effects of mutations in the WxxxE and endoplasmic reticulum membrane retention/retrieval signal motifs of WtsE on the virulence of Pantoea stewartii subsp. stewartii DC283. A, Whorls of sweet corn seedlings were inoculated and rated. Disease severity ratings, scoring for lesion formation, were taken daily and the area under the disease progress curve (AUDPC) was calculated for days 1 to 6 after inoculation. Disease severity ratings are shown for day 5 after inoculation. Mean ratings \pm standard deviation were calculated from 24 to 31 plants per strain and are representative of three trials. B, Growth of wildtype Pantoea stewartii subsp. stewartii and wtsE derivatives in sweet corn seedlings. Whorls were inoculated with $5 \times 10^{6} \mathrm{CFU} / \mathrm{plant}$. At daily intervals, viable cell counts were done for each of four plants per strain. The experiment was done twice and bacterial populations \pm standard deviation are the combined means from both experiments. The following Pantoea stewartii subsp. stewartii strains were tested: DC283 (wild-type), AA005 wtsE::aphT, JH037

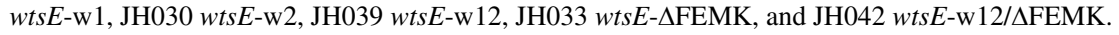


(Fig. 4A), whereas $P$. syringae pv. phaseolicola strains with the w12 or $\triangle$ FEMK derivatives of WtsE did not show any apparent cell death activity. To determine whether these motifs were also important for the suppression of $P$. syringae pv. phaseolicola-induced defenses, we examined callose deposition and PR-1 protein accumulation after infiltration of $P$. $s y$ ringae pv. phaseolicola expressing WtsE or its derivatives. WtsE suppressed $P$. syringae pv. phaseolicola-induced small callose deposits by approximately $50 \%$ and large callose deposits by approximately $90 \%$. WtsE also suppressed $P$. syringae pv. phaseolicola-induced accumulation of PR-1 by 50 to $90 \%$ in individual biological replicates. In contrast, the w12 and $\triangle F E M K$ mutant proteins failed to significantly suppress callose deposition (Fig. 4B) and PR-1 protein accumulation (Fig. 4C). These results indicate that, in addition to their role in the induction of disease-associated cell death, these motifs are also important for suppression of $P$. syringae pv. phaseolicola-induced defenses by WtsE.

\section{The WxxxE and ERMRS motifs are required}

for AvrE-mediated virulence in $P$. syringae pv. tomato.

To determine whether the requirement for the WxxxE and predicted ERMRS motifs is unique to WtsE or a more general feature of AvrE-family effectors, we studied AvrE, which is a major virulence factor of the A. thaliana and tomato pathogen $P$. syringae pv. tomato DC3000. We made two double mutations in the WxxxE motifs of AvrE (w1w2 [W393A/W829A] and e1e2 [E397A/E833A]) (Fig. 5A). We also mutated the two $\mathrm{K}$ residues (KK1787-88AA) within the putative C-terminal ERMRS motif (Fig. 5A). All of the mutations were made in
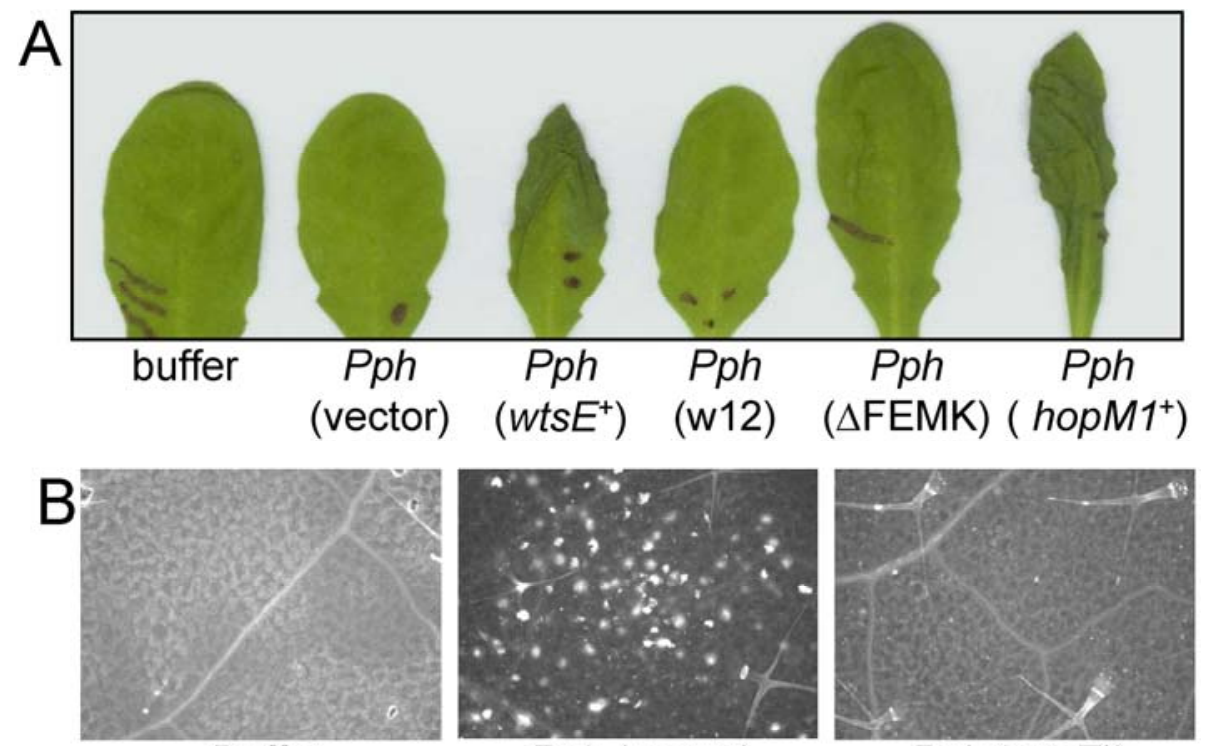

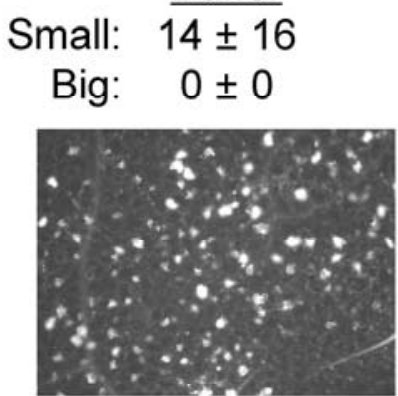

Pph (w12)

Small: $882 \pm 134$

Big: $61 \pm 30$

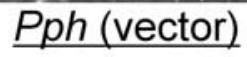

$1080 \pm 269$

$58 \pm 11$
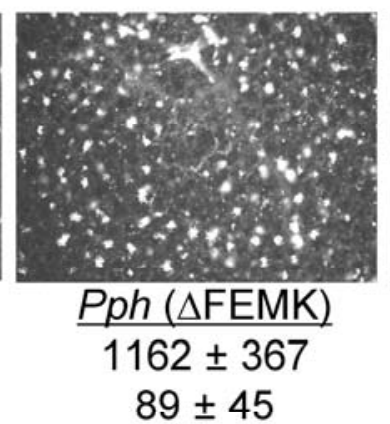

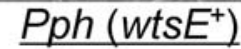

$514 \pm 252$

$2 \pm 3$

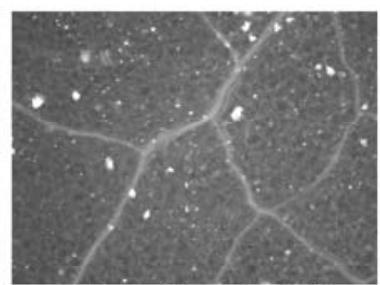

Pph $\left(h o p M 1^{+}\right)$

$427 \pm 172$

$12 \pm 6$

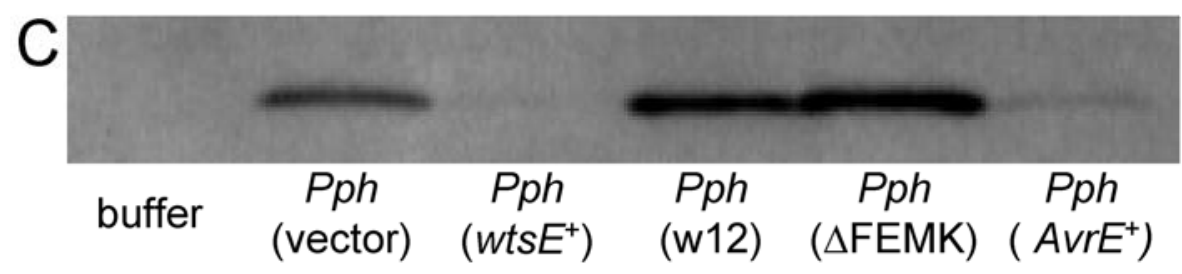

Fig. 4. Effect of mutating the WxxxE and endoplasmic reticulum membrane retention/retrieval signal motifs in WtsE on cell-death-inducing and defensesuppressing activities in Arabidopsis thaliana. Wild-type WtsE and derivatives of WtsE, HopM1, or AvrE were delivered by infiltration of Pseudomonas syringae pv. phaseolicola $(P p h)$ NPS3121 (at $1 \times 10^{8} \mathrm{CFU} / \mathrm{ml}$ ) carrying the following expression plasmids: $\mathrm{pJH} 082$ wtsEF ${ }^{+}$, pJH083 wtsE- $\Delta \mathrm{FEMK}, \mathrm{pJH} 084$

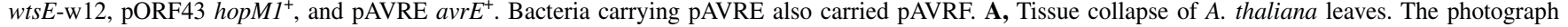
was taken $24 \mathrm{~h}$ after infiltration. B, Callose deposition visualized by fluorescence microscopy at $15 \mathrm{~h}$ after infiltration. Counts of small (<20 microns in diameter) and large (>20 microns in diameter) callose deposits are the means \pm standard deviation from five replications. C, PR-1 protein expression detected by Western blot analysis at $48 \mathrm{~h}$ after infiltration. 
pAVRE. Together with pAVRF (encoding AvrF, the putative molecular chaperone for AvrE secretion), the wild-type or mutant pAVRE plasmid was transformed into the $P$. syringae $\mathrm{pv}$. tomato $\triangle \mathrm{CEL}$ mutant, which lacks the functionally redundant avrE and hopM1 genes (Alfano et al. 2000; Badel et al. 2006; DebRoy et al. 2004).

We then examined the ability of the avrE mutants to complement the virulence defect of the $\triangle \mathrm{CEL}$ mutant. As reported previously (DebRoy et al. 2004), the $\triangle$ CEL mutant was severely reduced in multiplication (wild-type DC3000 reached $>100$ fold higher populations at 3 days after inoculation) and caused
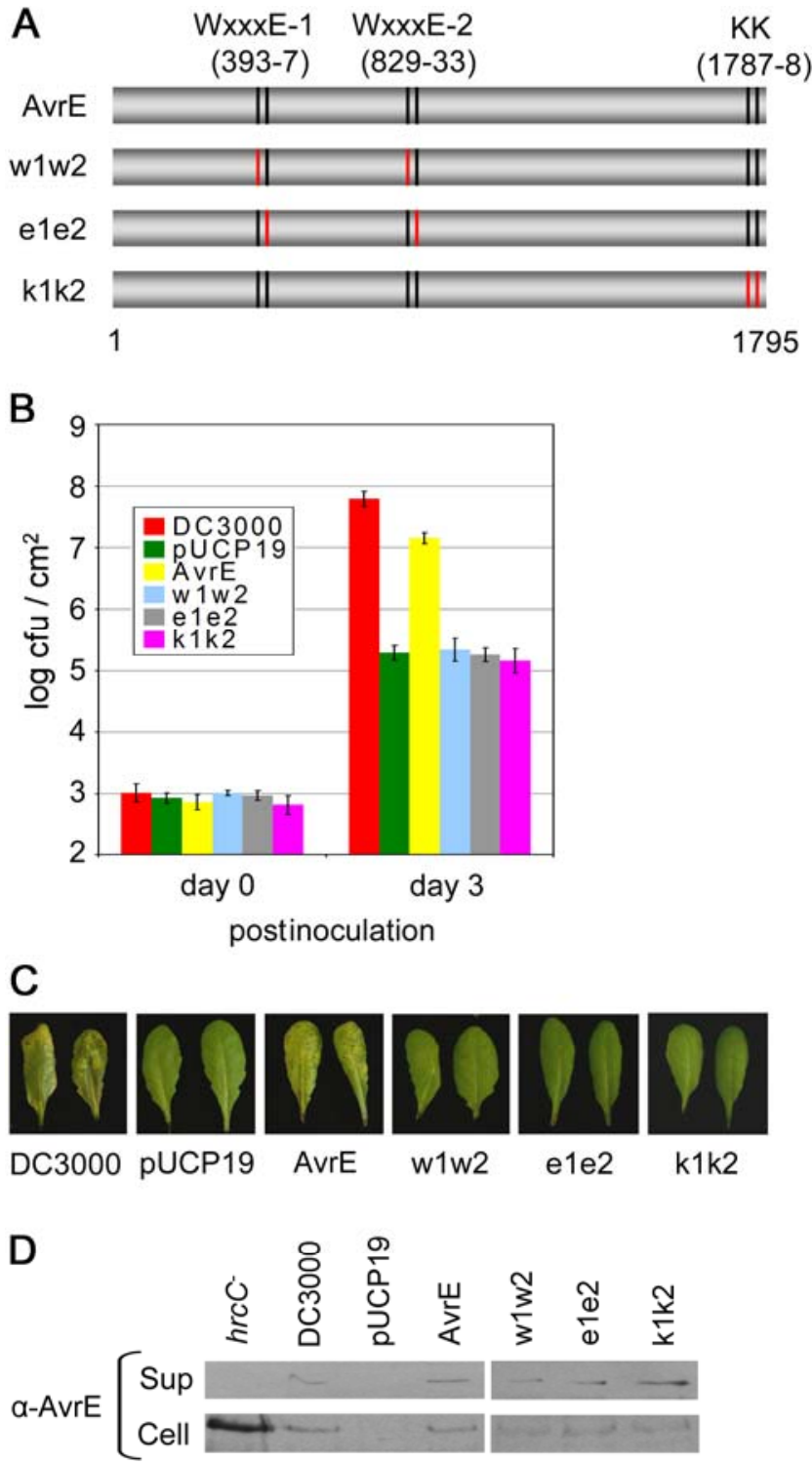

Fig. 5. WxxxE and endoplasmic reticulum membrane retention/retrieval signal motifs are required for the virulence activity of Pseudomonas syringae pv. tomato AvrE in Arabidopsis thaliana. A, Diagram of the AvrE protein, indicating the locations of the motifs and various mutations introduced. Numbers indicate the amino acid positions. B, Bacterial populations in $A$. thaliana Col-0 leaves at 3 days after inoculation. Leaves were inoculated by hand infiltration with $1 \times 10^{6} \mathrm{CFU} / \mathrm{ml}$ of $P$. syringae pv. tomato $\triangle \mathrm{CEL}$ bacteria carrying wild-type or mutant pAVRE and pAVRF using a needleless syringe. C, Disease symptoms at 3 days after inoculation. D, Immunoblot analysis of the production and secretion of wild-type and mutant AvrE proteins in $P$. syringae pv. tomato $\triangle \mathrm{CEL}$. Bacteria were grown in hrp-inducing liquid medium. Cultures were separated into supernatant (Sup) and cell (Cell) fractions by centrifugation. AvrE proteins in total lysates were detected by immunoblotting using an AvrE antibody. little or no disease symptoms in A. thaliana (Fig. 5B and C). pAVRE (along with pAVRF) restored the in planta growth of the $\triangle$ CEL mutant and production of disease symptoms to near the level of wild-type DC3000 (Fig. 5B and C). All mutant derivatives of AvrE were defective in the virulence functions assessed by bacterial growth and disease symptoms (Fig. 5B and $\mathrm{C}$ ). As a control, we verified that none of the mutations significantly impaired AvrE production or secretion in the $\triangle$ CEL mutant (Fig. 5D).

\section{DISCUSSION}

AvrE-family proteins are conserved in several important genera of gram-negative plant-pathogenic bacteria and there is clear genetic evidence that they are crucial to their virulence. Because the $a v r E$-family genes are part of a conserved TTSS PAI, it is likely that these effectors have played a major role in the evolution of plant-pathogenic bacteria from commensals. For technical reasons, it has been historically difficult to study the virulence mechanisms of AvrE-family effectors. Not only are these effectors extremely large proteins but they also induce cell death when expressed in plants or yeast (Ham et al. 2008; Meng et al. 2006). Although induction of cell death in both plants and yeast suggest that AvrE-family proteins may target a cellular process that is fundamental to eukaryotic cells, it has precluded the use of several experimental approaches (e.g., transgenic expression and yeast two-hybrid assays with full-length effector proteins) that have proven to be useful in the study of other effectors. The lack of overall sequence similarities to proteins of known functions has also hindered hypothesis-driven experiments. In this context, the identification of WxxxE motifs putatively involved in G-protein mimicry and the genetic demonstration of their importance in virulence mark a significant advance in our understanding of how these important effectors contribute to bacterial pathogenesis in plants. Moreover, our results suggest that manipulating host pathways by mimicking host G-proteins could be a widespread virulence mechanism employed not only by animal pathogens but also by plant pathogens. At this point, we are not in a position to demonstrate biochemically that WtsE or AvrE have the same effects on plant cells as a known activated G-protein because the targets of these effectors and their effects on plant cells are unknown. However, the likelihood that changing only two amino acids at different positions in two such large proteins with so little amino acid identity to each other would have similar dramatic affects on their function seems rather remote. Furthermore, mutating these residues is unlikely to have a nonspecific effect, such as disrupting protein structure, because mutating each residue alone in WtsE has little to no effect on its function.

It is interesting to note that the $\mathrm{WxxxE}$ and predicted ERMRS motifs are found in all of the AvrE-family members that have been shown to make large virulence contributions, such as those from Pantoea stewartii subsp. stewartii, P. syringae pv. tomato, and E. amylovora. It is possible that the absence of the WxxxE or ERMRS motifs in P. atrosepticum and some strains of $P$. viridiflava is somehow related to their different pathogenic lifestyles. Pantoea stewartii subsp. stewartii, $P$. syringae pv. tomato, and E. amylovora are hemibiotrophic pathogens, whereas $P$. atrosepticum and some strains of $P$. viridiflava are necrotrophic, soft-rot pathogens, which rely on cell-wall-degrading enzymes more than type III effectors as major virulence factors. Mutant studies have shown that the virulence contribution of $\mathrm{DspE}$ in $P$. atrosepticum appears to be less obvious than in Pantoea stewartii subsp. stewartii, $P$. syringae pv. tomato, and E. amylovora (Holeva et al. 2004).

Although the presence of WxxxE motifs indicates that G-protein mimicry may be a common mode of action among most 
AvrE-family members, the activity of individual AvrE-family effectors may be host adapted. For example, unlike native AvrE, WtsE is unable to promote the growth of $P$. syringae pv. tomato $\triangle \mathrm{CEL}$ in A. thaliana, and P. agglomerans pv. gypsophilae DspE is unable to complement a Pantoea stewartii subsp. stewartii $w t s E$ mutant in maize (data not shown). Furthermore, AvrEfamily members are likely to have additional virulence activities independent of G-protein mimicry. This notion is supported by the large size of the AvrE-family proteins and our finding that $P$. stewartii subsp. stewartii strains carrying the wtsE-w12 and $w t s E-\Delta$ FEMK mutations still produce a few small lesions and grow in corn significantly better than a nonpathogenic wtsE null mutant and nearly as well as the wild-type parent. Such putative additional virulence activities may explain why $P$. atrosepticum retains an AvrE effector gene that lacks a WxxxE motif. Alternatively, variant motifs, such as WxxxD, may also function in Gprotein mimicry, in which case all AvrE-family members might engage in this activity.
As discussed above, AvrE-family effectors are very interesting because they both promote host cell death and suppress basal defenses (Boureau et al. 2006; DebRoy et al. 2004; Ham et al. 2008). Prior to this study, however, it was unknown whether these dual functions were mediated by distinct activities or resulted from interconnected effects of a single activity. The large size of the AvrE-family effectors would be consistent with their being multifunctional. For example, in susceptible hosts these effectors could use one domain (activity) to disrupt membrane permeability by inducing HR-like cell death while employing another domain to control the damage, thus avoiding a full-blown HR and instead causing the Wts symptom common to many bacterial diseases. However, we provide evidence here that disease-associated cell death, HR elicitation, and defense suppression all require the same $\mathrm{WxxxE}$ and putative ERMRS motifs in WtsE and AvrE. Therefore, to carry out these activities, AvrE-family effectors may target a single pathway or, alternatively, mimic more than one G-protein to

Table 1. Plasmids and bacterial strains used in this study

\begin{tabular}{|c|c|c|}
\hline Plasmids and strains & Description $^{a}$ & Source or reference ${ }^{b}$ \\
\hline \multicolumn{3}{|l|}{ Agrobacterium tumefaciens } \\
\hline C58C1 & Vir $^{-}$, prototrophic strain, Rif ${ }^{r}$ & Van Larebeke et al. 1974 \\
\hline \multicolumn{3}{|l|}{ Escherichia coli } \\
\hline DH5 $\alpha$ & $\begin{array}{l}\text { mcrBC } C^{+} \text {supE44 } \triangle \text { lacU169 (f80 lacZ4M15) hsdR17 recA1 endA1 gyrA96 thi-1 } \\
\text { relA1 }\end{array}$ & Invitrogen \\
\hline MC4100 & araD139 $\triangle(\arg F-l a c) 205 \lambda^{-}$flbB5301 ptsF25 relA1 rpsL150 deoC1 & Casadaban 1976; CGSC \\
\hline \multicolumn{3}{|c|}{ Pantoea stewartii subsp. stewartii } \\
\hline DC283 & A Nal $^{\mathrm{r}}$ derivative of the wild-type strain SS104 & Coplin et al. 1986 \\
\hline DM711 & DC283 hrpJ79::Tn3HoHoI, Ap ${ }^{\mathrm{r}}$ & Frederick et al. 2001 \\
\hline DM5101 & A wtsE::miniTn5gus derivative of DC283, $\mathrm{Km}^{\mathrm{r}}$ & Ham et al. 2006 \\
\hline AA005 & A wtsE::aphT derivative of DC283, $\mathrm{Km}^{\mathrm{r}}$ & Ham et al. 2006 \\
\hline JH030 & A derivative of DC283 expressing WtsE-W840A & This study \\
\hline JH033 & A derivative of DC283 expressing WtsE $\Delta$ aa1831-1834 & This study \\
\hline JH037 & A derivative of DC283 expressing WtsE-W694A & This study \\
\hline JH039 & A derivative of DC283 expressing WtsE-W694A/W840A & This study \\
\hline JH042 & A derivative of DC283 expressing WtsE-W694A/W840A and WtsE- $\Delta$ aa1-236 & This study \\
\hline \multicolumn{3}{|c|}{ Pseudomonas syringae pv. phaseolicola } \\
\hline NPS3121 & A wild-type strain, Rif $^{r}$ & Lindgren et al. 1986 \\
\hline \multicolumn{3}{|l|}{ P. syringae pv. tomato } \\
\hline DC3000 & Wild-type, Rif ${ }^{r}$ & Cuppels 1986 \\
\hline DC3000 $\triangle \mathrm{CEL}$ & DC3000, $\Delta$ CEL:: $\Omega S p / S m$, Rif $^{r}$ & Alfano et al. 2000 \\
\hline DC3000 hrcC & DC3000, $h r c C:: \operatorname{miniTn} 5 \mathrm{Cm}, \operatorname{Rif}^{\mathrm{r}} \mathrm{Cm}^{\mathrm{r}}$ & Yuan and He 1996 \\
\hline \multicolumn{3}{|l|}{ Plasmids } \\
\hline pAA007 & pLAFR3 with 8.9-kb EcoRI/BamHI fragment carrying $w t s E$ and $w t s F, \mathrm{Tc}^{\mathrm{r}}$ & Ham et al. 2006 \\
\hline pAVRE & pUCP19 containing $a v r E$ and its own promoter, $\mathrm{Ap}^{\mathrm{r}}$ & Nomura et al. 2006 \\
\hline pAVRF & pDSK5 19 containing $a v r F$ with its own promoter, $\mathrm{Km}^{\mathrm{r}}$ & Nomura et al. 2006 \\
\hline pAVRE-w1w2 & Derivative of pAVRE expressing AvrE-W393A/W829A, Ap ${ }^{r}$ & This study \\
\hline pAVRE-e1e2 & Derivative of pAVRE expressing AvrE-E397A/E833A, Ap ${ }^{\mathrm{r}}$ & This study \\
\hline pAVRE-k1k2 & Derivative of pAVRE expressing AvrE-K1787A/K1788A, Ap ${ }^{r}$ & This study \\
\hline pBluescript $\mathrm{KS}$ and SK & ColE1 $\alpha$-lacZ, Ap ${ }^{\mathrm{r}}$ & Stratagene \\
\hline pCR $4^{\mathrm{r}}-\mathrm{TOPO}{ }^{\mathrm{r}}$ & A TOPO vector used for cloning PCR products, $\mathrm{Ap}^{\mathrm{r}}, \mathrm{Km}^{\mathrm{r}}$ & Invitrogen \\
\hline pCPP2156 & A cosmid clone carrying the Dickeya dadantii hrp cluster, $\mathrm{Sp}^{\mathrm{r}}$ & Ham et al. 1998 \\
\hline pGDG & Binary vector for agroinfiltration, derivative of pCAMBIA with $35 \mathrm{~S}$ promoter and & \\
\hline & $\mathrm{GFP}, \mathrm{Km}^{\mathrm{r}}$ & Goodin et al. 2002 \\
\hline pJH021 & $\begin{array}{l}\text { pBluescriptSK }(+) \text { clone of the } 6.4-\mathrm{Kb} E c o \mathrm{RI} / \text { Bam } \mathrm{HI} \text { fragment from } \mathrm{pJH} 001 \\
\text { carrying the } w t s E F \text { operon with its native promoter, } \mathrm{Ap}^{\mathrm{r}}\end{array}$ & Ham et al. 2008 \\
\hline pJH023 & Derivative of pJH021 with WtsE- $\Delta$ aa1831-1834, $\mathrm{Ap}^{\mathrm{r}}$ & Ham et al. 2008 \\
\hline pJH050 & Derivative of pJH021 with WtsE-W694A, Ap ${ }^{\mathrm{r}}$ & This study \\
\hline pJH052 & Derivative of pJH021 with WtsE-W840A, $\mathrm{Ap}^{\mathrm{r}}$ & This study \\
\hline pJH055 & Derivative of pJH021 with WtsE-W694A/W840A, Ap ${ }^{r}$ & This study \\
\hline pJH059 & Derivative of $\mathrm{pJHI} 02 \mathrm{G}$ with $\triangle \mathrm{FEMK}$ in WtsE, $\mathrm{Km}^{\mathrm{r}}$ & This study \\
\hline pJH063 & Derivative of pJH102G with W694A/W840A in WtsE, $\mathrm{Km}^{\mathrm{r}}$ & This study \\
\hline $\mathrm{pJH} 101 \mathrm{G}$ & pGDG::wtsE, $\mathrm{Km}^{\mathrm{r}}$ & This study \\
\hline pJH102G & pGDG::wtsE- $\Delta$ aa1-236, $\mathrm{Km}^{\mathrm{r}}$ & This study \\
\hline pJH103G & pGDG::wtsE- $\Delta \mathrm{aa} 1-492, \mathrm{Km}^{\mathrm{r}}$ & This study \\
\hline pLD55 & A suicide vector with R6K ori, $\alpha$ lacZ, tetAR, $\mathrm{Ap}^{\mathrm{r}}$ & Metcalf et al. 1996 \\
\hline pORF43 & pUCP19 carrying shcM-hopPtoM with the native $s h c M$ gene promoter, $\mathrm{Ap}^{\mathrm{r}}$ & Badel et al. 2003 \\
\hline pRF205 & pVK100 with a 1.7-kb HindIII fragment containing $\mathrm{P}_{l a c}-h r p S^{+}, \mathrm{Tc}^{\mathrm{r}}$ & Frederick et al. 1993 \\
\hline
\end{tabular}

${ }^{\mathrm{a}} \mathrm{Rif}^{\mathrm{r}}, \mathrm{Nal}^{\mathrm{r}}, \mathrm{Ap}^{\mathrm{r}}, \mathrm{Km}^{\mathrm{r}}, \mathrm{Cm}^{\mathrm{r}}, \mathrm{Tc}^{\mathrm{r}}$, and $\mathrm{Sp}^{\mathrm{r}}$ indicate resistant to rifampicin, nalidixic acid, ampicillin, kanamycin, chloramphenicol, tetracycline, and spectinomycin, respectively; $\mathrm{PCR}=$ polymerase chain reaction; $\mathrm{GFP}=$ green fluorescent protein .

${ }^{\mathrm{b}}$ CGSC $=$ Coli Genetic Stock Center at Yale University. 
target multiple host cellular processes. In the case of the nonhost HR, this common target or targets could be guarded by an $\mathrm{R}$-protein. Interestingly, a function of $\mathrm{WtsE}$ that is independent of its WxxxE and putative ERMRS motifs also contributes to the growth of Pantoea stewartii subsp. stewartii in corn. The nature of this additional activity is unknown.

Small G-proteins are central regulators of cytoskeleton dynamics and intracellular vesicle trafficking in eukaryotes, including higher plants (Samaj et al. 2006; Vernoud et al. 2003). Future research will be aimed at determining the mechanisms by which AvrE-family effectors manipulate host G-protein pathways to perturb the cytoskeleton or vesicular trafficking. Notably, P. syringae HopM1 interacts with and promotes degradation of several host targets, including AtMIN7, a guanine exchange factor that is predicted to activate small G-proteins (Nomura et al. 2006). Though sequence unrelated, HopM1 is functionally redundant with AvrE for the virulence of $P$. syringae pv. tomato. Thus, AvrE-family effectors may suppress defenses by perturbing G-protein-regulated processes, including export of antimicrobial cargo such as phytoalexins or PR-proteins and production of cell-wall defenses such as callose deposition. Meng and associates (2006) have shown that DspA interacts with apple receptor-like kinases that are putatively involved in host defense. G-protein mimicry could also suppress activation-associated internalization of this class of proteins (Robatzek et al. 2006). In addition, sustained perturbation of normal vesicle trafficking or cytoskeleton dynamics may lead to host cell death. Thus, G-protein-mimicry may explain the dual function of AvrE-family effectors in suppression of host basal defenses and induction of disease symptoms.

\section{MATERIALS AND METHODS}

\section{Bacterial strains and their growth conditions.}

Bacterial strains and plasmids used in this study are described in Table 1. Escherichia coli, Pantoea stewartii subsp. stewartii, and Agrobacterium tumefaciens strains were routinely grown and maintained in Luria-Bertani (LB) media (Sambrook and Russel 2001) at 28 to $30^{\circ} \mathrm{C}$. P. syringae pvs. phaseolicola and tomato strains were grown in King's B agar at $30^{\circ} \mathrm{C}$ (Schaad et al. 2001) or on $\mathrm{LB}$ without $\mathrm{NaCl}$ (for P. syringae pv. tomato). Appropriate antibiotics were added at the following concentrations: ampicillin at $200 \mu \mathrm{g} / \mathrm{ml}$, kanamycin at $100 \mu \mathrm{g} / \mathrm{ml}$ for $P$. syringae and $50 \mu \mathrm{g} / \mathrm{ml}$ for Pantoea stewartii subsp. stewartii and Escherichia coli, nalidixic acid at $20 \mu \mathrm{g} / \mathrm{ml}$, spectinomycin at $50 \mu \mathrm{g} / \mathrm{ml}$, rifampicin at $100 \mu \mathrm{g} / \mathrm{ml}$, and tetracycline at 25 $\mu \mathrm{g} / \mathrm{ml}$.

\section{DNA manipulation, transformation, and sequencing.}

Standard protocols described by Sambrook and Russel (2001) were used for gene-cloning procedures, such as DNA isolation, digestion with restriction enzymes, and ligation. Appropriate Qiagen (Valencia, CA, U.S.A.) kits were used for isolation of DNA fragments from agarose gels or polymerase chain reaction (PCR). Cloning of PCR products was conducted with Platinum Taq DNA polymerase High Fidelity and TOPO vectors (Invitrogen, Carlsbad, CA, U.S.A.) following the manufacturer's protocols and all the clones obtained were confirmed by DNA sequencing with an ABI 3700 capillary electrophoresis sequencer (Applied Biosystems, Foster City, CA, U.S.A.) at The Ohio State University Plant-Microbe Genomic Facility. Oligonucleotides were purchased from Integrated DNA Technologies, Inc. (Coralville, IA, U.S.A.) Bacterial transformation was conducted by either electroporation using a GenePulser (Bio-Rad Laboratories, Hercules, CA, U.S.A.) apparatus set to $200 \Omega$ and $1.5 \mathrm{KV}$ or triparental mating as previously described (Merighi et al. 2003).
Plant assays.

Sweet corn seedlings (Zea mays cv. Seneca Horizon), tobacco (N. tabacum cv. Bottom Special), N. benthamiana, and beet (Beta vulgaris cv. Red Ace Hybrid) were grown and maintained in growth chambers set to $30^{\circ} \mathrm{C}, 90 \%$ humidity, and a cycle of 18 and $6 \mathrm{~h}$, day and night, respectively. A. thaliana (ecotype Col-0) plants were grown in a growth room at $23^{\circ} \mathrm{C}$ for $8 \mathrm{~h}$ of light and $16^{\circ} \mathrm{C}$ for $16 \mathrm{~h}$ of darkness for WtsE studies or at $20^{\circ} \mathrm{C}$ with a 12-h light-and-dark cycle for AvrE studies.

Pantoea stewartii subsp. stewartii and Escherichia coli suspensions for the cell death assays in host and nonhosts were prepared as previously described (Ham et al. 2006). For the cell-death assay in sweet corn, 5-day-old seedlings in 5-inchpots were inverted, submerged in beakers containing the bacterial suspensions $\left(10^{9} \mathrm{CFU} / \mathrm{ml}\right)$, and vacuum-infiltrated (Ham et al. 2006). For the cell-death assays in nonhost plants, the bacterial suspensions were infiltrated into the abaxial side of the leaves with needleless syringes. Conductivity assays to measure electrolyte leakage from corn leaf disks were done as previously described (Ham et al. 2007).

Procedures for virulence assays of Pantoea stewartii subsp. stewartii strains in sweet corn seedlings are described in our previous studies (Frederick et al. 2001; Ham et al. 2006). Briefly, bacterial suspensions containing $1 \times 10^{7} \mathrm{CFU} / \mathrm{ml}$ in buffered $0.2 \%$ Tween 40 were added to the whorls of 7-day-old seedlings without wounding and disease severity was rated on a 0 -to-3 scale $(0=$ no symptoms, $1=$ a few lesions but no ooze, $2=$ many lesions and some ooze, and 3 = confluent lesions and ooze). For in planta growth assays, individual seedlings were homogenized with a Powergen 700 homogenizer (Fisher Scientific, Pittsburg, PA, U.S.A.) in $5 \mathrm{ml}$ of $10 \mathrm{mM}$ potassium phosphate buffer ( $\mathrm{pH} 7.0)$ and dilution plated on LB agar supplemented with nalidixic acid. Bacterial growth and disease assays in A. thaliana with $P$. syringae strains were performed following previously described methods (Hauck et al. 2003).

\section{Bioinformatic techniques.}

Amino acid sequences of AvrE-family proteins were obtained from the National Center for Biotechnology Information database and the putative ERMRS motifs of the AvrE-family proteins were identified by the PSORT II program (Nakai and Kanehisa 1992). Alignment of AvrE-family proteins and creation of a neighbor-joining tree were conducted by using the software MEGA 4.1 (Tamura et al. 2007).

\section{Callose staining and PR-1 detection.}

For callose staining, the infiltrated leaves were bleached with lactophenol solution, then stained with $0.01 \%$ aniline blue in $150 \mathrm{mM} \mathrm{K}_{2} \mathrm{HPO}_{4}$, and observed under a Nikon Eclipse 80i epifluorescence microscope (Nikon, Melville, NY, U.S.A.) as previously described (Kim et al. 2005). PR-1 proteins produced in A. thaliana were detected by Western blot analysis (Kim et al. 2005) using ECL-plus reagents and a Storm phosphorimager (GE Healthcare, Piscataway, NJ, U.S.A.).

\section{WtsE and AvrE constructs.}

The GeneTailor site-directed mutagenesis system (Invitrogen) was used to create the W694A, W840A, and $\triangle$ aa18311834 mutations in $w t s E$. The procedure for generating WtsE$\triangle$ aa1831-1834 was described in our previous study (Ham et al. 2008). For W694A and W840A mutations, the 3.8-kb BamHI/ NcoI-cut fragment of pAA008 containing the $5^{\prime}$ half-portion of $w t s E$ (Ham et al. 2006) was initially cloned into pET41b(+) (Novagen, San Diego, CA, U.S.A.). In turn, the 2.4-kb ClaI/ $N c o$ I region of $w t s E$, which contains both WxxxE1 and WxxxE2 motifs, was subcloned into pBSKS(+) using the ClaI site in $w t s E$ and the KpnI site in pET41. The plasmid DNA of this 
subclone was then used as a template for PCR with overlapping primers. For the W694A mutation, the template plasmid DNA was initially methylated with SssI DNA methylase (New England Biolabs, Inc., Ipswich, MA, U.S.A.) and PCR was carried out with an overlapping primer set consisting of forward primer 5'-TTGATCAGCTTACCAGGGGCGCCACA GAAGCAGAG-3' and reverse primer 5'-TGGTAAGCTGATC AAAATAGTGCACTTTGCCATCC-3'. The PCR products were subsequently introduced into Escherichia coli DH5 $\alpha$, which degrades the methylated parental DNA. Plasmids with the W694A mutation were initially screened for the KasI site introduced by the forward primer (underlined), and then confirmed by DNA sequencing. The same procedure was used to create the W840A mutation, except that the overlapping primer set 5'-TTTCGCCAGGCACGTGAGCATGCGCAGCA GGGTGA-3' and 5'-ACGTGCCTGGCGAAATATCTCTCC TTCGCGGGTCA-3' was used and mutant plasmids were screened for the $S p h \mathrm{I}$ site introduced by the forward primer (underlined). These were also confirmed by DNA sequencing. For the W694A/W840A double mutation, the same procedure was carried out using the plasmid with the W694A mutation as the template and the primer set for the W840A mutation. Then, the 854-bp PstI-NcoI fragments carrying each mutation were substituted for the corresponding region of pJH001, which contains the entire wtsEF operon with its own promoter in pCR4-TOPO (Ham et al. 2008). These inserts were finally excised from pJH001 as 6.4-kb EcoRI/BamHI fragments and recloned into $\mathrm{pBSSK}(+)$, generating $\mathrm{pJH} 050$, pJH052, and pJH055 for the W694A, W840A, and W694A/W840A derivatives of WtsE, respectively. In addition, the same inserts were also cloned in pDSK519 (Keen et al. 1988) to produce pJH082, pJH083, pJH084, and pJH085, which express WtsE derivatives for wild-type, $\Delta$ aa1831-1834, W694A/W840A, and W694A/ W840A/ $\triangle$ aa1831-1834 respectively.

For Agrobacterium-mediated transient expression, pJH101G $w t s E^{+}, \mathrm{pJH} 102 \mathrm{G} w t s E-\Delta \mathrm{aa} 1-236$, and $\mathrm{pJH} 103 \mathrm{G} w t s E-\Delta \mathrm{aa} 1-$ 492 were constructed as described by Ham and associates (2008) for pJH101, pJH102, and pJH103, respectively. However, the vector pGDG (Goodin et al. 2002), which creates Nterminal green fluorescent protein fusions, was used instead of pGD. For pJH059, which is a derivative of $\mathrm{pJH} 102 \mathrm{G}$ with wtsE- $\Delta$ FEMK, the 5.5-kb XhoI/BamHI fragment from $\mathrm{pJH} 023$ was ligated into XhoI/BamHI-cut pGDG. For pJH063, which is a derivative of $\mathrm{pJH} 102 \mathrm{G}$ with $w t s E$-w12, the $5.5-\mathrm{kb} X h o \mathrm{I} /$ BamHI fragment from pJH055 was ligated into XhoI/BamHIcut pGDG.

For recombination into the chromosome of Pantoea stewartii subsp. stewartii, the 2.4-kb SalI-KpnI fragments of wtsE with each W694A/W840 mutation and the 2.4-kb KpnI-BamHI fragment of pJH023, which carries the $\Delta$ aa1831-1834 mutation, were cloned into suicide vector pLD55 and introduced into wild-type Pantoea stewartii subsp. stewartii DC283 followed by screening the recombinant strains as described by Merighi and associates (2006). The resulting chromosomal $w t s E$ mutants were $\mathrm{JH} 030$, JH033, JH037, JH039, and JH042, which carry the W840A, $\triangle$ aa1831-1834, W694A, W694A/W840A, and W694A/W840A/Daa1831-1834 mutations, respectively. Each Pantoea stewartii subsp. stewartii mutant was confirmed by PCR and subsequent diagnostic restriction enzyme digestions of the incorporated restriction sites mentioned above and in our previous study (Ham et al. 2008).

Site-directed mutagenesis of $a v r E$ in pAVRE was performed using the Quikchange XL site-directed mutagenesis kit (Stratagene, La Jolla, CA, U.S.A.) with sequence-specific primers for each mutation (Supplementary Table 1). The constructs were transformed into $\triangle \mathrm{CEL}$ mutant bacteria carrying pAVRF. All mutations were verified by sequencing.

\section{Protein expression and secretion assays.}

For AvrE from P. syringae pv. tomato, bacteria were grown on low-salt $\mathrm{LB}$ plates for $24 \mathrm{~h}$ at $28^{\circ} \mathrm{C}$ and then suspended in sterile water. Bacteria were washed two times with sterile water, resuspended in $h r p$-inducing fructose minimal medium (Jin and He 2001), and then incubated with shaking at $18^{\circ} \mathrm{C}$ for $15 \mathrm{~h}$. Cultures were separated into cell and supernatant fractions by centrifugation at $12,000 \times g$. The cell and supernatant fractions were concentrated 5 and 50 times, respectively. Proteins were separated on sodium dodecyl sulfate polyacrylamide gel electrophoresis gels and transferred to Immobilon-P membrane (Millipore Corp., Billerica, MA, U.S.A.). Immunoblot analyses were performed using rabbit polyclonal AvrE antibodies produced by Cocalico Biologicals, Inc. (Reamstown, PA, U.S.A.). For expression and secretion of WtsE from Pantoea stewartii subsp. stewartii, cells were grown in hrp-inducing medium, culture supernatants were concentrated 350 -fold, and assays by Western blots, using rabbit $\mathrm{DspE}_{E a}$ antibodies, were done as described previously (Ham et al. 2006).

\section{ACKNOWLEDGMENTS}

We thank S. V. Beer for the anti-DspE $E_{E a}$ antibodies. This project was supported by grants from the National Research Initiative of the United States Department of Agriculture Cooperative State Research, Education, and Extension Service (grant no. 2005-35319-15328) and the Ohio Agricultural Research and Development Center to D. L. Coplin and D. Mackey, from the National Science Foundation (MCB-0718882) to D. Mackey, and from National Institute of Health and Department of Energy to S.-Y. He.

\section{LITERATURE CITED}

Alfano, J. R., Charkowski, A. O., Deng, W. L., Badel, J. L., PetnickiOcwieja, T., van Dijk, K., and Collmer, A. 2000. The Pseudomonas syringae Hrp pathogenicity island has a tripartite mosaic structure composed of a cluster of type III secretion genes bounded by exchangeable effector and conserved effector loci that contribute to parasitic fitness and pathogenicity in plants. Proc. Natl. Acad. Sci. U.S.A. 97:48564861

Alto, N. M., Shao, F., Lazar, C. S., Brost, R. L., Chua, G., Mattoo, S., McMahon, S. A., Ghosh, P., Hughes, T. R., Boone, C., and Dixon, J. E. 2006. Identification of a bacterial type III effector family with $G$ protein mimicry functions. Cell 124:133-145.

Araki, H., Innan, H., Kreitman, M., and Bergelson, J. 2007. Molecular evolution of pathogenicity-island genes in Pseudomonas viridiflava. Genetics 177:1031-1041.

Arbeloa, A., Bulgin, R. R., MacKenzie, G., Shaw, R. K., Pallen, M. J., Crepin, V. F., Berger, C. N., and Frankel, G. 2008. Subversion of actin dynamics by EspM effectors of attaching and effacing bacterial pathogens. Cell. Microbiol. 10:1429-1441.

Badel, J. L., Nomura, K., Bandyopadhyay, S., Shimizu, R., Collmer, A., and He, S. Y. 2003. Pseudomonas syringae pv. tomato DC3000 HopPtoM (CEL ORF3) is important for lesion formation but not growth in tomato and is secreted and translocated by the Hrp type III secretion system in a chaperone-dependent manner. Mol. Microbiol. 49:1239-1251.

Badel, J. L., Shimizu, R., Oh, H. S., and Collmer, A. 2006. A Pseudomonas syringae pv. tomato avrE1/hopM1 mutant is severely reduced in growth and lesion formation in tomato. Mol. Plant-Microbe Interact. 19:99-111.

Bogdanove, A., Kim, J. F., Wei, Z., Kolchinsky, P., Charkowski, A. O., Conklin, A. K., Collmer, A., and Beer, S. V. 1998. Homology and functional similarity of an hrp-linked pathogenicity locus, $d s p E F$, of Erwinia amylovora and the avirulence locus avrE of Pseudomonas syringae pathovar tomato. Proc. Natl. Acad. Sci. U.S.A. 95:1325-1330.

Boureau, T., ElMaarouf-Bouteau, H., Garnier, A., Brisset, M. N., Perino, C., Pucheu, I., and Barny, M. A. 2006. DspA/E, a type III effector essential for Erwinia amylovora pathogenicity and growth in planta, induces cell death in host apple and nonhost tobacco plants. Mol. PlantMicrobe Interact. 19:16-24.

Casadaban, M. J. 1976. Transposition and fusion of the lac genes to selected promoters in Escherichia coli using bacteriophage lambda and Mu. J. Mol. Biol. 104:541-555.

Coplin, D. L., Frederick, R. D., Majerczak, D. R., and Haas, E. S. 1986. 
Molecular cloning of virulence genes from Erwinia stewartii. J. Bacteriol. 168:619-623.

Cuppels, D. A. 1986. Generation and Characterization of Tn5 Insertion Mutations in Pseudomonas syringae pv. tomato. Appl. Environ. Microbiol. 51:323-327.

da Cunha, L., Sreerekha, M. V., and Mackey, D. 2007. Defense suppression by virulence effectors of bacterial phytopathogens. Curr. Opin. Plant Biol. 10:349-357.

DebRoy, S., Thilmony, R., Kwack, Y. B., Nomura, K., and He, S. Y. 2004 A family of conserved bacterial effectors inhibits salicylic acid-mediated basal immunity and promotes disease necrosis in plants. Proc. Natl. Acad. Sci. U.S.A. 101:9927-9932.

Frederick, R. D., Majerczak, D. R., and Coplin, D. L. 1993. Erwinia stewartii WtsA, a positive regulator of pathogenicity gene expression, is similar to Pseudomonas syringae pv. phaseolicola HrpS. Mol. Microbiol. 9:477-485.

Frederick, R. D., Ahmad, M., Majerczak, D. R., Arroyo-Rodriguez, A. S. Manulis, S., and Coplin, D. L. 2001. Genetic organization of the Pantoea stewartii subsp. stewartii hrp gene cluster and sequence analysis of the $h r p A, h r p C, h r p N$ and $w t s E$ operons. Mol. Plant-Microbe Interact. 14:1213-1222.

Gohre, V., and Robatzek, S. 2008. Breaking the barriers: Microbial effector molecules subvert plant immunity. Annu. Rev. Phytopathol. 46:189-215.

Goodin, M. M., Dietzgen, R. G., Schichnes, D., Ruzin, S., and Jackson, A. O. 2002. pGD vectors: versatile tools for the expression of green and red fluorescent protein fusions in agroinfiltrated plant leaves. Plant J. 31:375-383.

Ham, J. H., Bauer, D. W., Fouts, D. E., and Collmer, A. 1998. A cloned Erwinia chrysanthemi Hrp (type III protein secretion) system functions in Escherichia coli to deliver Pseudomonas syringae Avr signals to plant cells and to secrete Avr proteins in culture. Proc. Natl. Acad. Sci. U.S.A. 95:10206-10211.

Ham, J. H., Majerczak, D. R., Arroyo-Rodriguez, A. S., Mackey, D., and Coplin, D. L. 2006. WtsE, an AvrE-family effector protein from Pantoea stewartii subsp. stewartii, causes disease-associated cell death in corn and requires a chaperone protein for stability. Mol. Plant-Microbe Interact. 19:1092-1102.

Ham, J. H., Kim, M. G., Lee, S. Y., and Mackey, D. 2007. Layered basal defenses underlie non-host resistance of Arabidopsis to Pseudomonas syringae pv. phaseolicola. Plant J. 51:604-616.

Ham, J. H., Majerczak, D. R., Ewert, S., Mysore-Venkatara, S., Mackey, D., and Coplin, D. L. 2008. WtsE, an AvrE-family type III effector protein of Pantoea stewartii subsp. stewartii, causes cell death in nonhost plants. Mol. Plant Pathol. 9:633-643.

Hauck, P., Thilmony, R., and He, S. Y. 2003. A Pseudomonas syringae type III effector suppresses cell wall-based extracellular defense in susceptible Arabidopsis plants. Proc. Natl. Acad. Sci. U.S.A. 100:8577-8582.

He, S. Y., Nomura, K., and Whittam, T. S. 2004. Type III protein secretion mechanism in mammalian and plant pathogens. Biochim. Biophys. Acta 1694:181-206.

Holeva, M. C., Bell, K. S., Hyman, L. J., Avrova, A. O., Whisson, S. C., Birch, P. R. J., and Toth, I. K. 2004. Use of a pooled transposon mutation grid to demonstrate roles in disease development for Erwinia carotovora subsp. atroseptica putative type III secreted effector (DspE/A) and helper $(\mathrm{HrpN})$ proteins. Mol. Plant-Microbe Interact. 17:943-950.

Jin, Q., and He, S. Y. 2001. Role of the Hrp pilus in type III protein secretion in Pseudomonas syringae. Science 294:2556-2558.

Joardar, V., Lindeberg, M., Jackson, R. W., Selengut, J., Dodson, R., Brinkac, L. M., Daugherty, S. C., DeBoy, R., Durkin, A. S., Giglio, M. G., Madupu, R., Nelson, W. C., Rosovitz, M. J., Sullivan, S., Crabtree, J., Creasy, T., Davidsen, T., Haft, D. H., Zafar, N., Zhou, L. W., Halpin, R., Holley, T., Khouri, H., Feldblyum, T., White, O., Fraser, C. M., Chatterjee, A. K., Cartinhour, S., Schneider, D. J., Mansfield, J., Collmer, A., and Buell, C. R. 2005. Whole-genome sequence analysis of Pseudomonas syringae pv. phaseolicola 1448A reveals divergence among pathovars in genes involved in virulence and transposition. J. Bacteriol. 187:6488-6498.

Keen, N. T., Tamaki, S., Kobayashi, D., and Trollinger, D. 1988. Improved broad-host-range plasmids for DNA cloning in gram-negative bacteria. Gene 70:191-197.
Kim, M. G., da Cunha, L., McFall, A. J., Belkhadir, Y., DebRoy, S., Dangl, J. L., and Mackey, D. 2005. Two Pseudomonas syringae type III effectors inhibit RIN4-regulated basal defense in Arabidopsis. Cell 121:749759.

Lindgren, P. B., Peet, R. C., and Panapoulos, N. J. 1986. Gene cluster of Pseudomonas syringae pv. phaseolicola controls pathogenicity on bean plants and hypersensitivity on nonhost plants. J. Bacteriol. 168:512522.

Lorang, J. M., and Keen, N. T. 1995. Characterization of avrE from Pseudomonas syringae pv. tomato: a hrp-linked avirulence locus consisting of at least two transcriptional units. Mol. Plant-Microbe Interact. 8:4957.

Meng, X., Bonasera, J. M., Kim, J. F., Nissinen, R. M., and Beer, S. V. 2006. Apple proteins that interact with DspA/E, a pathogenicity effector of Erwinia amylovora, the fire blight pathogen. Mol. Plant-Microbe Interact. 19:53-61.

Merighi, M., Majerczak, D. R., Stover, E. H., and Coplin, D. L. 2003. The HrpX/HrpY two-component system activates hrpS expression, the first step in the regulatory cascade controlling the Hrp regulon in Pantoea stewartii subsp. stewartii. Mol. Plant-Microbe Interact. 16:238-248.

Merighi, M., Majerczak, D. R., Zianni, M., Tessanne, K., and Coplin, D. L. 2006. Molecular characterization of Pantoea stewartii subsp. stewartii HrpY, a conserved response regulator of the Hrp type III secretion system, and its interaction with the hrpS promoter. J. Bacteriol. 188:5089-5100.

Metcalf, W. W., Jiang, W., Daniels, L. L., Kim, S. K., Haldimann, A., and Wanner, B. L. 1996. Conditionally replicative and conjugative plasmids carrying lacZ $\alpha$ for cloning, mutagenesis, and allele replacement in bacteria. Plasmid 35:1-13.

Nakai, K., and Kanehisa, M. 1992. A knowledge base for predicting protein localization sites in eukaryotic cells. Genomics 14:897-911.

Nomura, K., Debroy, S., Lee, Y. H., Pumplin, N., Jones, J., and He, S. Y. 2006. A bacterial virulence protein suppresses host innate immunity to cause plant disease. Science 313:220-223.

Robatzek, S., Chinchilla, D., and Boller, T. 2006. Ligand-induced endocytosis of the pattern recognition receptor FLS2 in Arabidopsis. Genes Dev. 20:537-542.

Samaj, J., Muller, J., Beck, M., Bohm, N., and Menzel, D. 2006. Vesicular trafficking, cytoskeleton and signaling in root hairs and pollen tubes. Trends Plant Sci. 11:594-600.

Sambrook, J., and Russel, D. W. 2001. Molecular Cloning: A Laboratory Manual. Cold Spring Harbor Laboratory Press, Cold Spring Harbor, NY, U.S.A.

Schaad, N. W., Jones, J. B., and Chun, W. 2001. Laboratory Guide for Identification of Plant Pathogenic Bacteria. American Phytopathological Society Press, St. Paul, MN, U.S.A.

Speth, E. B., Lee, Y. N., and He, S. Y. 2007. Pathogen virulence factors as molecular probes of basic plant cellular functions. Curr. Opin. Plant Biol. 10:580-586

Tamura, K., Dudley, J., Nei, M., and Kumar, S. 2007. MEGA4: Molecular Evolutionary Genetics Analysis (MEGA) software version 4.0. Mol. Biol. Evol. 24:1596-1599.

Van Larebeke, N., Engler, G., Holsters, M., Van den Elsacker, S., Zaenen, I., Schilperoort, R. A., and Schell, J. 1974. Large plasmid in Agrobacterium tumefaciens essential for crown gall-inducing ability. Nature 252:169-170.

Vernoud, V., Horton, A. C., Yang, Z., and Nielsen, E. 2003. Analysis of the small GTPase gene superfamily of Arabidopsis. Plant Physiol. 131:1191-1208.

Yuan, J., and He, S. Y. 1996. The Pseudomonas syringae Hrp regulation and secretion system controls the production and secretion of multiple extracellular proteins. J. Bacteriol. 178:6399-6402.

\section{AUTHOR-RECOMMENDED INTERNET RESOURCES}

National Center for Biotechnology Information database: www.ncbi.nlm.nih.gov

PSORT II program: psort.nibb.ac.jp. 